\title{
Research on Blended Teaching Model Applied in College English Grammar Teaching from the Perspective of TDT Approach -A Case Study of Guangzhou Donghua Vocational College
}

\author{
Ning $\mathrm{Xu}^{1, *}$ \\ ${ }^{1}$ Guangzhou Donghua Vocational College, Guangzhou, China, 510540 \\ *Corresponding author.Email: ning.june@hotmail.com
}

\begin{abstract}
Grammar learning is known for one of the critical elements in vocational college English, especially in College English Test level B (CETB). Yet traditional college English grammar teaching is also known for its low efficiency and unsatisfactory learning experience as well as passive learning atmosphere. Due to the outbreak of Covid-19, the shift to distant learning during the pandemic brought about a challenge but also an opportunity for educators. In light of the spirit of College English Reformation, how to maintain and optimize the learning experience with support of information communication technology (ICT) becomes an increasingly urgent question. Guided by blended approach, based on grounded theory, this study is to explore the impact of blended approach on students. Based on the results of class observation, questionnaires to 10 English teachers and 962 students in Guangzhou Donghua Vocational College (GDVC), the study identifies prominent problems emerged in the college English grammar teaching and offers constructive solutions with Discover, Learn, Practice, Collaborate and Assess (DLPCA) blended model, which promotes the learning outcome, enriches the learning experience and lightens the learning atmosphere. This research updates the application of ICT in college English grammar teaching and provides a different perspective to blended language teaching under the outbreak of Covid-19 pandemic context.
\end{abstract}

Keywords: Covid-19 pandemic, blended theory, college English, grammar learning

\section{INTRODUCTION}

Due to the sudden outbreak of Covid-19, people realized that the traditional face-to-face teaching model became fragile and unreliable and had to turn to online teaching. With most of pandemic cases under controlled in China, blended both of synchronous and asynchronous approach to learning and teaching are gaining currency in the changed higher education landscape. Though some studies showed there was no significant difference in learning outcome between online and offline teaching, hardly any research had been done to explore how to conduct blended model in an appropriate proportion. In this study, by conducting an empirical research, the author aims to explore an effective blended model in conducting English grammar teaching with respective to Freeman's Three Dimensions Theory (TDT), taking students in GDVC as an example [1].

\section{ENGLISH GRAMMAR TEACHING IN COLLEGE}

According to TDT, instead of considering grammar teaching as a hierarchical introduction of meaning and form it should be considered as three wedges of a pie which inter-related and have repercussions for each other. Freeman points out that three elements interact with each other, and lacking of the context influences students' understanding of the usage of it. In traditional college English class, teachers spend much time and energy on the form, and yet little or even no attention is paid to meaning and context, which causes the major problem leading to unsatisfied learning outcome. According to TDT, grammar teaching should follow the following procedures: first, the lecturer should introduce the meaning of grammar points with meaningful context (explicit grammar teaching); then, the lecturer should provide communicative tasks, which should be 
appropriately challenging, to engage students (implicit grammar teaching). To set up an authentic context which is closely related to students' daily lives is critical, in which language output will be generated more naturally and spontaneously. Jim Scrivener states that teaching grammar should be conducted under setting context, through eliciting and asking conceptual checking questions [2]. The study of Teaching Grammar in Context: Why and How? [3] suggests that "Learning grammar in context will allow learners to see how rules can be used in sentences". Revisiting the Debate of Grammar Teaching: A Young Scholar's Perspective indicates that grammar teaching should consist the following procedures: (1) presentation and practice; (2) presentation without practice; (3) practice without presentation [4].

\section{BLENDED THEORY AND TEACHING MODEL}

\subsection{Definition of blended theory}

According to Driscoll, blended learning refers to four different concepts: (1) to combine or mix modes of web-based technology to accomplish an educational goal. (2) to combine various pedagogical approaches to produce an optimal learning outcome with or without instructional technology. Blended learning environments, involving the "blending" of face-to-face, online, print-based and other media to create an overall learning environment for students, are now commonplace in universities abroad [6].

Garrison and Vaughan stated that blended learning represent a new approach, a mix of classroom and online activities, consistent with goals of specific courses programs [7]. It brings into consideration a range of options that require revisiting how students learn in deep and meaningful ways. In the near future all teaching will be supported by digital or net-based flexible solutions in their educational experiences. In such case, how to create blended leaning more efficiently and meaningfully in college English grammar teaching, especially taking the requirements of College English into consideration, is an indispensable question to be answered.

\subsection{Grammar teaching model in regard to blended theory}

According to the finding identified by Jared $\mathrm{M}$. Carman, there are five key ingredients in College English grammar teaching: (1)live events; (2)self-paced learning; (3)collaboration; (4)assessment; (5) reference or performance support materials [8]. The proposed teaching model employed in this study is designed based on the key elements and TDT by Freeman [1]. In the pre-study section, it focuses mainly on introduction to the assignment. The first step is synchronous learning section, in which teachers assign task for the unit. Next, online prevision assignments, in which are in form of self-paced learning, are to be completed before the class. Thus, context which is related to the learning task is introduced so that students have proper psychological preparation for the following sections. It also provides context for online collaborative communicative task such as discussion, brainstorming. During the class, in-class activity, such as feedback on prevision task, collaborative project, group presentation, discussion, comments and reflection will be conducted. Consolidation activity which will be applied to meaningful authentic context should be involved at after learning activity which is to consolidate the knowledge. The decision of proportion of both synchronous and asynchronous teaching is the key element in developing a blended learning program that cater to the objectives of teaching. 


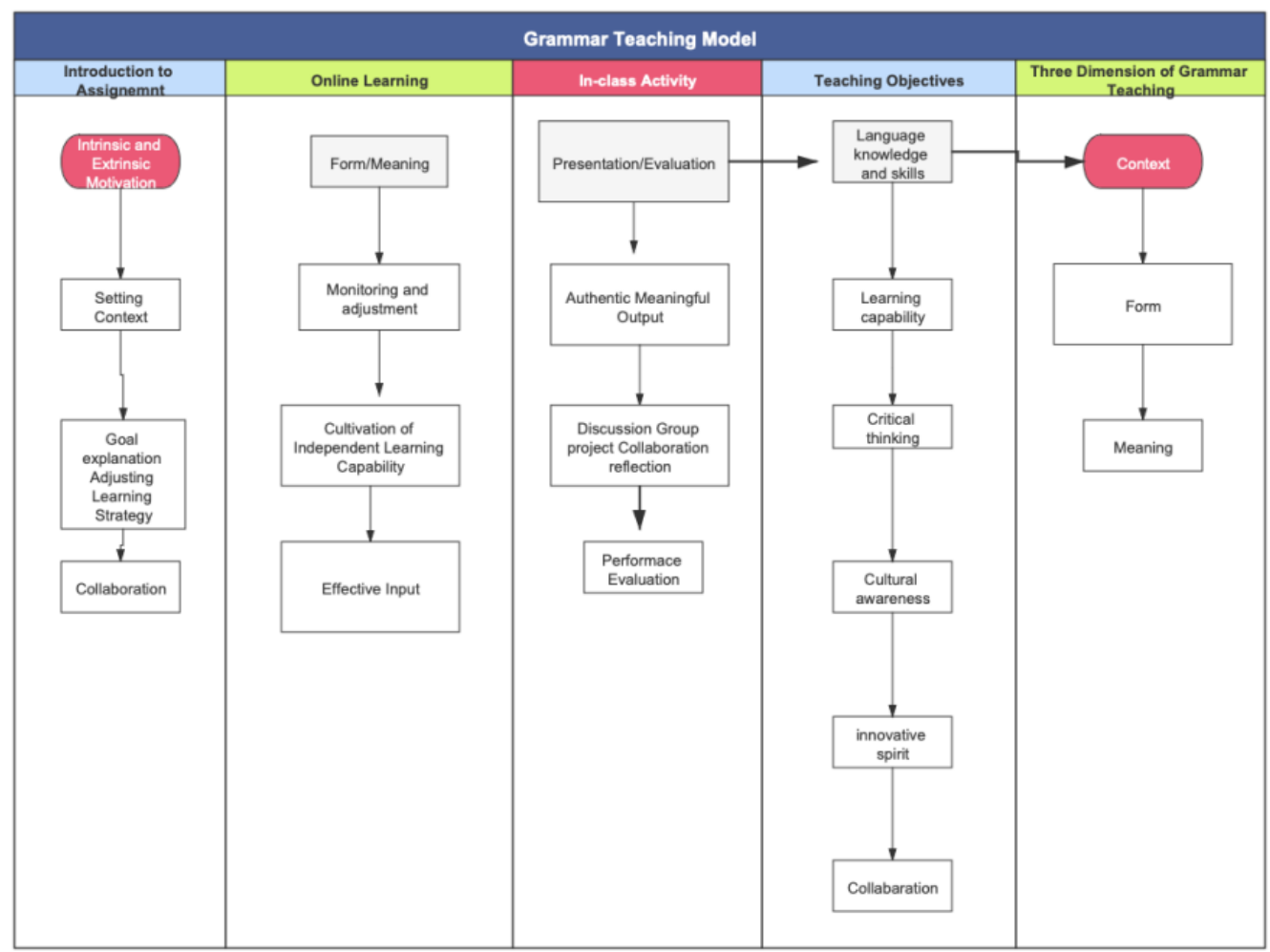

Figure 1 Grammar teaching design based on blended theory

\section{RESEARCH DESIGN}

This study is to compare the learning experience and learning outcome by conducting blended approach in college English grammar teaching in Guangzhou Donghua Vocational College. The hypothesis questions is: since blending teaching model is gaining increasing emphasis, how do teachers maintain and optimize the learning outcome of it in college English grammar teaching. Incorporating with update ICT (Information Computer Technology), this empirical research is to address the question by using both quantitative and qualitative method. First, all the participants are required to participate in a pretest, which is a standardized test adapted from CETB past paper; after the test, 962 first year non-English major students are divided into two groups. Group1 (G1, n=482) is the controlled group, in which students study in traditional face-to-face model; group $2(\mathrm{G} 2, \mathrm{n}=480)$ is the experiential group, which follows the blended synchronous and asynchronous teaching model. Taking data from CETB score, questionnaires, interview and class observation as the evidence, the researcher compares the learning outcome and learning experience of traditional teaching model and blended teaching model in grammar learning.

\subsection{Chaoxing platform}

Among all the applications ICT, one particular device that facilitates the offline learning is Chaoxing platform, with which students conduct in two hours of offline autonomous learning, from video watching, brainstorming, to online discussion. It is currently one of the most popular e-learning platform in China. It has multiple functions in supporting both synchronous, in-class activity, and asynchronous, self-paced learning. Chaoxing platform supports learning as knowledge serves like a consistent flow during the whole learning process.

\subsection{Participants}

The participants of this study were 963 first grade non-English major students in Guangzhou Donghua Vocational College. They are from 6 different classes of the same major, both of the groups have similar gender structure (male $>90 \%$, female $<10 \%$ ) and are having four English classes as compulsory course each week (two hours of additional online independent learning for experimental class). Students from both groups are working on the CETB exam in the end of the academic year. 


\subsection{Implementation}

\subsubsection{Pretest}

In the beginning of the semester, after taking the college entrance exam, all the first year students are required to take a pretest, which is adapted from CETB past paper. That helps teachers to adjust teaching focus based on students level. About $6.25 \%$ of students in controlled class and $9.38 \%$ in experimental class reached score 80 or above; $43.6 \%$ of controlled class students and $46.9 \%$ of experimental class students ranged from 61 to 79 ; around $50 \%$ of students from both of the classes failed the test. Based on the result of the test, students in controlled class and experimental class were at similar English level before the study.

Table 1. Results of pretest

\begin{tabular}{|l|l|l|l|l|}
\hline Class types & $\begin{array}{l}\text { Student } \\
\text { amount }\end{array}$ & $\begin{array}{l}\text { Score } \\
80 \text { or } \\
\text { above }\end{array}$ & $61-79$ & $\begin{array}{l}60 \\
\text { below }\end{array}$ \\
\hline $\begin{array}{l}\text { Controlled } \\
\text { Class }\end{array}$ & 482 & 30 & 210 & 242 \\
\hline $\begin{array}{l}\text { Experimental } \\
\text { Class }\end{array}$ & 480 & 45 & 225 & 210 \\
\hline
\end{tabular}

Table 2. Example of blended college English grammar design

\subsubsection{Course design}

For controlled class, the course design follows the traditional face-to-face teaching model. Students meet their teachers twice a week with 90 minutes class duration each. It contains 32 teaching weeks in one academic year. On the other hand, in the experimental class, which adopts blended model, study is conducted based on DLPCA (Discover, Learn, Practice, Collaborate, Assess) blended model. As there is no specified grammar lecture, the topic is to be introduced in detailed reading section. In the light of Freeman's TDT principle, the teaching of grammar is designed with tasked based approach which serves the purpose of setting up context to facilitate learning. During the lecture, incorporating ICT, such as kahoot, chaoxing platform, teacher assigns collaborative work such as group projects and presentation tasks. Thus, the face-to-face meeting functions as a space for identifying difficulties, topic discussions and learning demonstration. Instead of tedious lecturing and endless drilling, such practice, in regard to students learning center ideology, encourages students to actively engage in discussions and identify their problems so that immediate feedback is to be provided.

\begin{tabular}{|c|c|}
\hline Topic & lastic Pollution--Global Environmental Protection Awareness. \\
\hline $\begin{array}{l}\text { Before } \\
\text { Class/ } \\
\text { Self-paced } \\
\text { learning }\end{array}$ & $\begin{array}{l}\text { Discover and Learn: } \\
\text { Through watching the video, reading magazine, students conduct online independent learning. } \\
\text { By watching the video online, students understand the severity of plastic } \\
\text { pollution. Hence, relevant topics and contexts are introduced, which stimulates active } \\
\text { inquiry from the students and cultivates critical thinking during the process. }\end{array}$ \\
\hline $\begin{array}{l}\text { While Class/ } \\
\text { Collaborativ } \\
\text { e learning }\end{array}$ & $\begin{array}{l}\text { Collaboration and Assessment } \\
\text { Task 1. To distinguish finite and nonfinite. } \\
\text { By highlighting phrases, phrases comparison, active inquiry, students generate the differences be } \\
\text { tween } \\
\text { finite and nonfinite in groups. The teacher highlights the language points after making } \\
\text { comment onstudents' work. } \\
\text { Task 2. The usage of infinitive. } \\
\text { By watching video Xiaoming's Plastic Lifestyle, in light of environmental protection, } \\
\text { students develop } \\
\text { some constructive suggestions for Xiaoming's habit with infinitive } \\
\text { clauses. } \\
\text { Task 3. The usage of gerund. } \\
\text { Through contextual assignment (Xiaoming decided to write a community proposal-to Protect } \\
\text { Community Environment to Stay away from Plastic Waste.), sample sentences analysis, sentence } \\
\text { pattern imitation, students conduct a co-editing form via Padlet, online co-editing blog, to } \\
\text { form the sentences for Xiaoming's proposal with gerund clauses. }\end{array}$ \\
\hline
\end{tabular}




\begin{tabular}{|l|l|}
\hline & $\begin{array}{l}\text { Based on the results of peer review, teacher comments and reveals the winner of the task. } \\
\text { Task 4. The usage of past participial. } \\
\text { Through contextual assignment (in order to protect the environment for the world, } \\
\text { Xiaoming participated different activities, such as delivering lectures, fund raising, making } \\
\text { donation, etc. and wrote a reflection on all these activities.), sample analysis, } \\
\text { imitation, students write the reflection on it with past participial clauses in form of groups. Based } \\
\text { on the results of peer review, the teacher comments and reveals the winner of the task. }\end{array}$ \\
\hline $\begin{array}{l}\text { After Class/ } / \text { Application and Consolidation } \\
\text { ional }\end{array}$ & $\begin{array}{l}\text { 1. To make a campus poster on environmental protection with nonfinite clauses—consolidation o } \\
\text { f grammar points. } \\
\text { 2. To participate in an online survey via Wenjuanxing-consolidation of environmental } \\
\text { protection awareness. }\end{array}$ \\
\hline
\end{tabular}

\subsection{Questionnaire}

In order to identify learning experience of given blended model, the researcher conducted a questionnaire investigation among students in experimental group. Questionnaire adapted from Zhang, which aimed at identifying students' learning experience and difficulty in blended learning was applied in the research [9]. It was designed in microsoft shared form format with 10 scale questions. It was sent by the end of semester to investigate on students' blended learning satisfaction.

Table 3. Questionnaire on blended learning experience

\begin{tabular}{|l|l|l|l|l|c|}
\hline & $\begin{array}{l}\text { Strongly } \\
\text { disagree }\end{array}$ & Disagree & Neutral & Agree & $\begin{array}{c}\text { Strongly } \\
\text { agree }\end{array}$ \\
\hline $\begin{array}{l}\text { 1. In time feedback from online } \\
\text { practice enhance my English } \\
\text { grammar. }\end{array}$ & $14 \%$ & $27 \%$ & $32 \%$ & $27 \%$ & $/$ \\
\hline $\begin{array}{l}\text { 2. Audio and pictures further my } \\
\text { understanding of the language. }\end{array}$ & -- & $14 \%$ & -- & $86 \%$ & -- \\
\hline $\begin{array}{l}\text { 3. Limited internet access affects } \\
\text { my online learning process. }\end{array}$ & $63.6 \%$ & $13.6 \%$ & $22.8 \%$ & -- & -- \\
\hline $\begin{array}{l}\text { 4. I do not like participating in } \\
\text { in-class discussion. }\end{array}$ & $95.5 \%$ & $4.5 \%$ & -- & -- & -- \\
\hline $\begin{array}{l}\text { 5. I become more aware of my } \\
\text { grammar while joining online } \\
\text { discussion. }\end{array}$ & -- & -- & $45.5 \%$ & $31.8 \%$ & $22.7 \%$ \\
\hline $\begin{array}{l}\text { 6. I do not enjoy conversation } \\
\text { with teacher during face-to-face } \\
\text { meeting. }\end{array}$ & $27.3 \%$ & $36.4 \%$ & $31.8 \%$ & $4.5 \%$ & -- \\
\hline $\begin{array}{l}\text { 7. I enjoy using knowledge point } \\
\text { to solve problems in class. }\end{array}$ & -- & $22.7 \%$ & $18.2 \%$ & $10.9 \%$ & $18.2 \%$ \\
\hline $\begin{array}{l}\text { 8. I sense less pressure via } \\
\text { online communication. }\end{array}$ & $13.6 \%$ & $22.7 \%$ & $27.4 \%$ & $31.8 \%$ & $4.5 \%$ \\
\hline $\begin{array}{l}\text { 9. Teacher provides sufficient } \\
\text { guidance for my study. }\end{array}$ & -- & -- & -- & $90.9 \%$ & $9 \%$ \\
\hline $\begin{array}{l}\text { 10. Teacher does not give } \\
\text { enough attention to problems I } \\
\text { encountered during learning. }\end{array}$ & $81.8 \%$ & $4.5 \%$ & $4.5 \%$ & $9.2 \%$ & -- \\
\hline
\end{tabular}


Inferred from result of the investigation, benefits identified by students of blended model is surprising. As $32 \%$ of students took neutral attitude towards the effect of in-time feedback from online practice, $27 \%$ considered it useful, and yet attitudes towards effect of asynchronous learning varied. However, more than $80 \%$ of students agreed that audio and pictures helped their understanding of the language which meant online asynchronous learning supported study and according to question 3, none of the student had been affected by the internet performance in GDVC; regarding to the flipped in-class learning and based on question 4 and 7, 100\% of students enjoyed participating in-class discussion and more than $70 \%$ of students enjoyed applying knowledge to real life problem; based on result of question 6 and 8 , there was no significant evidence of communication pressure on students in GDVC. From question 9 and 10, under blended model teacher were giving sufficient attention to students.

\subsection{Interview and class observation}

40 students randomly chosen from experimental group were invited for interview in regarding to learning experience and personal development, such as self-learning ability and collaborative study. During the interview the descriptive data such as 'enjoyable class environment', 'more communication' 'more reflection' had been noted. Most of them believed that it was very important for students to develop their grammar skills. About $64 \%$ of investigated students showed their willingness to improve their performance, $45.5 \%$ of them believed that grammar played an important role in enhancing language competence, and $40.9 \%$ of them also believed blended model developed their self-learning ability.

For experimental groups, classes were mainly conducted in task-based learning, project study and group presentation. During the class observation, the researcher had noticed that students had more interaction with their peers and more than $90 \%$ of the students were engaged in different form of group discussion.

\section{RESULTS AND DISCUSSION}

In considering the result of pretest, term final, CETB score, questionnaire, interview and class observation, several conclusions are drawn regarding to the application of blended model in college English grammar teaching process.

\subsection{Academic performance}

From the result of term finals and CETB exam, both the controlled group and experimental group have witnessed certain growth in their score, among which the average score of students from experimental group, with mean of 0.2 , higher than that of the controlled group, with mean of 0.13 . It suggests that by adopting blended model in teaching grammar in college English, it effectively enhances the academic performance and improves score in the exam.

There is a statistically significant difference in the performance of final exam between the blended learning group and the face-to-face group. The blended group did better than the group that did with a major difference of 1.3 .

\subsection{Learning motivation}

During the investigation, most of the interviewed students agree that blended model is more effectively in drawing their attention during the process. $84 \%$ of the students mentioned "fun" in their interview and more than $78 \%$ of students used either "refreshing" or "interesting" in describing the learning process. During the interview with teachers, above $90 \%$ of teachers believed that students were more actively engaged in the in-class activity with support of ICT. $50 \%$ of teachers described the class atmosphere as "lively", "vibrate" and "exciting", but $40 \%$ of them also agreed that the blended model was "time consuming", "less efficient" and 10\% considered blended approach made no significant difference from the traditional class in enhancing students' academic performance.

\subsection{Collaborative study}

Involvement of online study on Chaoxing platform is analyzed through the frequency of participation of the online discussion with group members and lecturers. A total of 11793 interactions were recorded in the summary log of Chaoxing platform over 34 lecture weeks. There were instances when some students had more than the average frequency of interaction in a week.

\section{CONCLUSION}

Based on the result of study, the application of DLPCA blended model in college English grammar teaching has an positive impact on enriching students learning experience, stimulating intrinsic motivation and most importantly enhancing academic performance. While the blended module is currently applied only to the grammar teaching in GDVC, it is evident that it should be adopted by other aspects of language as well. Also, with occasionally Covid-19 cases appeared in the community, blended module provides an opportunity for the educators to take a different perspective on the 
traditional teaching model and explore more possibilities in optimizing our teaching with modern ICT.

\section{AUTHORS' CONTRIBUTIONS}

This paper is independently completed by Ning Xu.

\section{ACKNOWLEDGMENTS}

The author is grateful to the university administration for providing supports to students on how to use the online portal. The author is also appreciative to Dr. Eric NG for contributing materials and input for the learning theories.

\section{REFERENCES}

[1] Larsen-Freeman, D. Teaching Grammar. In Celce-Murcia M. Teaching English as a Second or Foreign Language , Boston: Heinle \& Heinle, 1991, pp.279-283.

[2] Jim Scrivener. Teaching English Grammar: What to Teach and How to Teach It. Sydney: Macmillan Education, 2010.

[3] Meyer, J. Youga, J. Teaching Grammar in Context Why and How [J] The English Journal, 1990, 3(1):124-129.

[4] Mohammed Sadat. Revisiting the Debate of Grammar Teaching: A Young Scholar's Perspective [J] Sion-US English Teaching, 2017, 14(1):1-7.

[5] Ellis, Rob. Current Issues in the Teaching of Grammar: An SLA Perspective [M] TESOL Quarterly - Teachers of English to Speakers of Other Languages, 2006, 40(1):83-108.

[6] Driscoll, M. Blended Learning. E-Learning, 2002, 3(3), 26-29.

[7] Garrison, D. R., \& Vaughan, N. D. Blended Learning in Higher Education: Framework, Principles, and Guidelines. San Francisco: Jossey-Bass, 2008.

[8] Jared M. Carman. Blended Learning Design: Five Key Ingredients [EB/OL]. (2005-08-10) retrieved from http://www, agilantlearning, corn/pall/Blended\% 20Learning\% 20Design. pdf.

[9] Zhang Meng. The Implement of the Blended Learning Approach in College English Classroom. Shanghai International Studies University, 2010. 